\title{
Operating cost of sugarcane harvester in function of agricultural productivity and harvester age
}

\author{
Ângelo D. Banchi ${ }^{1}$, Angel P. Garcia ${ }^{2}$, Andrei Grespan ${ }^{2}$, Daniel Albiero ${ }^{2}$, \\ Luis G. A. Favarin ${ }^{1} \&$ Cezario B. Galvão \\ ${ }^{1}$ Assiste Engenharia Agrícola Eireli. Piracicaba, SP, Brasil, E-mail:angelo@assiste.com.br (Corresponding author) - ORCID: 0000-0002-3737-6082; \\ luisguilherme.favarin@gmail.com - ORCID: 0000-0002-2681-3734 \\ ${ }^{2}$ Universidade Estadual de Campinas/Faculdade de Engenharia Agrícola, Campinas, SP, Brasil, E-mail: angelpg@g.unicamp.br - ORCID: 0000-0002-8163-6638; \\ andreigrespan2@gmail.com - ORCID: 0000-0003-3764-2931; daniel.albiero@gmail.com - ORCID:0000-0001-6877-8618; cezariogalvao@gmail.com - ORCID: \\ 0000-0001-9933-8586
}

\begin{abstract}
The brazilian agriculture has expanded and improved its techniques in the last decades as well as the mechanization of sugarcane cultivation. Overall, the mechanization cost of this cultivation is the highest of the total cost of production in relation to other crops. That cost consists of several elements such as the cost of the harvester. This study aimed to develop a mathematical model that represents the operational cost of the harvester in relation to its operating life and agricultural productivity, parameters that are associated with its operational capacity. Simulations of this cost were conducted, raging the operating life of harvesters between 0 and $17,900 \mathrm{~h}$, and the agricultural productivity of the cultivation from 50 to $130 \mathrm{Mg} \mathrm{ha}^{-1}$. The results indicated an operating cost between $\mathrm{R} \$ 7.23$ (BRL) and $\mathrm{R} \$ 26.43 \mathrm{Mg}^{-1}$. It was verified that the operational cost is inversely proportional and nonlinear to productivity, and also directly proportional and nonlinear in relation to the age of the harvester.
\end{abstract}

Key words: economic performance indicators, multiple regression, agricultural management, agricultural machinery efficiency

\section{Custo operacional da colhedora de cana-de-açúcar em função da produtividade agrícola e idade da colhedora}

RESUMO: A agricultura brasileira tem expandido e melhorado suas técnicas nas últimas décadas, assim como a mecanização da cultura de cana-de-açúcar. Em geral, o custo da mecanização dessa cultura é o mais elevado dentre o custo total de produção em relação a outras culturas. Este custo é composto de vários componentes, tais como o custo da colhedora. Este trabalho teve por objetivo desenvolver um modelo matemático que represente o custo operacional da colhedora em função de sua vida e da produtividade agrícola, parâmetros esses associados à capacidade operacional da colhedora. Foram realizadas simulações deste custo, variando a vida útil das colhedoras entre 0 e $17.900 \mathrm{~h}$ e a produtividade agrícola da cultura variou de 50 a $130 \mathrm{Mg} \mathrm{ha}^{-1}$. Os resultados apresentaram um custo operacional entre $R \$ 7,23$ e $R \$ 26,43 \mathrm{Mg}^{-1}$. Verificou-se que o custo operacional é inversamente proporcional e não linear à produtividade e também diretamente proporcional e não linear à idade da colhedora.

Palavras-chave: indicadores de desempenho econômico, regressão múltipla, gestão agrícola, eficiência de máquinas agrícolas 


\section{INTRODUCTION}

In the period of 1980 and 2018, in Brazil the production of sugarcane cultivation accounted for 148 and 674 million tons, respectively (IBGE, 2018). During this period, the use of machinery was paramount for increasing production since such equipment generated productive results and reduction of costs, allowing greater agility in cultivation handling and improvement in harvest efficiency.

Studies of production in different sugarcane producing regions demonstrated that the higher average cost of the activity refers to mechanization, and the machinery that composes the system of mechanized harvesting are deemed the most expensive (Santos et al., 2014; Pereira, 2017).

The operating cost (OC) of the harvester is influenced by several factors, among which crop productivity is highlighted (Pereira et al., 2015). A study of willow plantations in the United States revealed the influence of the following parameters: plot size, plot shape in the field, yield, distance to the storage location, and type of harvest equipment, noting that to better assess the performance of the harvesting process it is important to analyze the interaction between these factors (Ebadian et al., 2018).

In this context, repair and maintenance expenses (RME) increase over the operating life of the machine, and a mathematical model for this phenomenon can be developed. Galvão et al. (2018) performed an important study on the operating life of transshipments, which are used in the process of mechanized agricultural harvesting of sugarcane and demonstrated the feasibility and usefulness of creating these models for a better evaluation of the process.

When determining the costs regarding the operating conditions of the sugarcane plantations in advance, considering their respective particularities in terms of agricultural productivity and age of the harvesting equipment reveals which operating situations are appropriate in addition to their sustainability concerning the sugarcane harvest. Considering the agricultural productivity of the cultivation and the operating life of the equipment as the variables, this study aims to determine a mathematical model for the operational costs of the harvester for different years and crops.

\section{Material ANd Methods}

Data were extracted on a monthly basis for four years from SISMA ${ }^{\bullet}$ fleet management software in eight sugarcane production units located in the Brazilian south-central region. Data were extracted by workers on these units, which had different grinding capabilities (total amount of sugarcane harvested per crop), under normal working conditions.

A summary of agronomic characteristics and the equipment used in the eight production units investigated are presented in Table 1.

As shown in Table 1, the database comprises 276 harvesters from two distinct manufacturers, whose equipment have an average operating life of $7,974 \mathrm{~h}$. The production unit has an annual grinding range from 2 to 5.3 million tons, and agricultural productivity ranges from 73 to $88.7 \mathrm{Mg} \mathrm{ha}^{-1}$.

The data were obtained from various processes that ranged from simple registration on information sheets to electronic records from on-board computers. Data were imported from recording systems and transferred to electronic spreadsheets. Information was divided according to sugarcane production units, manufacturers, and the harvesters' year of manufacture. Two distinct models of harvesters were addressed, with manufacturing years ranging from 2010 to 2015, and operating lives ranging between 0 and $17,900 \mathrm{~h}$. All harvesters had a single-pass, cut-and-chip system with engine power ranging from 251 to $263 \mathrm{KW}$.

The collection of information on the annual production of the harvester started after the load in a transshipment was completed. Information on the harvester operating in this transshipment process was retrieved. Once loaded and registered, the transshipment was moved to the transfer courtyard, where the load was transferred to a semi-trailer or to the platform of a road truck carrying the product to the discharge courtyard of the industrial unit. The truck was then weighed to determine its net load capacity.

Fixed costs, defined as ownership costs, which are independent of the use of the machine, comprise the cost of capital recovery, rates and OCs. In this study, cost of capital recovery represents values referring to the depreciation of equipment and capital interests (Santos et al., 2016b).

The following equation for the calculation of capital recovery was used.

$$
\mathrm{CRC}=(\mathrm{PP}-\mathrm{RV})\left[\frac{\mathrm{RA}(1+\mathrm{RA})^{\mathrm{n}}}{(1+\mathrm{RA})^{\mathrm{n}}-1}\right]+\mathrm{RV} \mathrm{RA}
$$

where:

CRC - capital recovery costs, $R \$$ year $^{-1}(B R L)$;

$\mathrm{PP}$ - purchase price, $\mathrm{R} \$$

$\mathrm{RV}$ - residual value, $\mathrm{R} \$$

RA - rate of attractiveness (\%); and,

n - number of estimated years of life.

Table 1. Summary of the data collected in sugarcane production units (2015 base year)

\begin{tabular}{|c|c|c|c|c|c|c|c|c|}
\hline \multirow{2}{*}{ Unit } & \multicolumn{3}{|c|}{ Amount of haverster } & \multirow{2}{*}{$\begin{array}{l}\text { Average operating } \\
\text { life (h) }\end{array}$} & \multirow{2}{*}{$\begin{array}{l}\text { Average age } \\
\text { (years) }\end{array}$} & \multirow{2}{*}{$\begin{array}{l}\text { Area } \\
\text { (ha) }\end{array}$} & \multirow{2}{*}{$\begin{array}{c}\text { Annual } \\
\text { production (Mg) }\end{array}$} & \multirow{2}{*}{$\begin{array}{c}\text { Sugarcane Productivity } \\
\left(\mathrm{Mg} \mathrm{ha}^{-1}\right)\end{array}$} \\
\hline & Man. 1 & Man. 2 & Total & & & & & \\
\hline$A$ & 21 & 17 & 38 & 6,548 & 2 & 38,578 & $3,421,874$ & 88.7 \\
\hline B & 10 & 16 & 26 & 6,525 & 2 & 27,931 & $2,135,049$ & 76.4 \\
\hline C & 20 & 6 & 26 & 6,591 & 2 & 28,290 & $2,481,611$ & 87.7 \\
\hline D & 14 & 13 & 27 & 10,457 & 4 & 30,907 & $2,700,000$ & 87.4 \\
\hline $\mathrm{E}$ & 17 & 27 & 44 & 7,767 & 4 & 41,276 & $3,482,881$ & 84.4 \\
\hline $\mathrm{F}$ & 17 & 8 & 25 & 7,260 & 4 & 24,404 & $2,047,533$ & 83.9 \\
\hline G & 22 & 11 & 33 & 8,488 & 4 & 39,032 & $2,849,302$ & 73.0 \\
\hline $\mathrm{H}$ & 31 & 26 & 57 & 10,161 & 4 & 63,095 & $5,300,000$ & 84.0 \\
\hline
\end{tabular}

Man - Manufacturer 
Based on various quotes from agricultural machinery dealerships, an average purchase price (PP) of $\mathrm{R} \$ 950,000.00$ per equipment and a residual value (RV) of $\mathrm{R} \$ 95,000.00$ after six years of use was considered. The average rate of attractiveness was $12 \%$ per year.

The cost of rates for agricultural machinery was disregarded. In the last five years, a slight change has been noticed in this scenario, in which some companies have been using insurance services for some operating classes of machines.

Wage costs comprise salaries and all labor charges. The following equation to calculate wage costs was used.

$$
\mathrm{WC}=\mathrm{NO} \text { MW AMWO LB }
$$

where:

WC - wage costs, $\mathrm{R} \$$ year $^{-1}$;

NO - number of operators;

MW - minimum wage value, $R$;

AMWO - amount of minimum wages the operator earns; and,

LB - labor charges that fall upon the operator's wage, \%.

From a survey conducted on sugarcane plantations, 3.6 operators are required per equipment; each operator earns three minimum wages. On average, labor charges represent $100 \%$ of the wage value.

Variable costs include fuel, lubricating oils, and repair and maintenance expenses (RME).

Fuel costs were determined by Eq. 3:

$$
\mathrm{FC}=\mathrm{CONSF} \text { USE PD }
$$

where:

FC - fuel costs, R\$ year ${ }^{-1}$;

CONSF - Harvester's fuel consumption, $\mathrm{L} \mathrm{h}^{-1}$;

USE - use of the harvester, $\mathrm{h}$; and,

$\mathrm{PD}$ - price of diesel oil, $\mathrm{R} \$ \mathrm{~L}^{-1}$.

The cost of lubricating oils, incurred by both the replacement and the pumping of these fluids, and was determined by Eq. 4

$$
\mathrm{CL}=\text { CONSL USE PL }
$$

where:

CL - costs on lubricating oils, $\mathrm{R} \$$ year $^{-1}$;

CONSL - consumption of lubricating oils per machine operating hour, $\mathrm{L} \mathrm{h}^{-1}$;

USE - annual use of the machine, $h$; and,

$\mathrm{PL}$ - price of lubricating oil, $\mathrm{R} \$ \mathrm{~L}^{-1}$.

RME is incurred when the machine is being used and is influenced by many factors such as the power of the equipment, adjustment of the machine, maintenance plan, age of the machine, operating location, and the operator's skill. Harvester RME in relation to the operating life of the equipment to state the range (Banchi et al., 2008), a factor that was also observed in a study on the RME of transshipments used in sugarcane harvesting operations (Galvão et al., 2018). Therefore, since this factor is not fixed, an empirical equation was used that represents the evolution of RME according to the operating life of the harvester, defined by Eq. 5 .

$$
\mathrm{RME}=(0.011751 \mathrm{X}+34.787231) \mathrm{USE}
$$

where:

RME - repair and maintenance expenses, $R \$$ year $^{-1}$;

USE - use of the harvester, $h$; and,

$\mathrm{X}$ - operating life of the harvester, $\mathrm{h}$.

By adding capital recovery costs, operators' wages, fuel, lubricating oils, and the RME per year, and subsequently dividing them by the amount of raw material harvested by the harvester in the respective year, the OC of the harvester is obtained.

To estimate the amount of raw materials harvested by the harvester per year, the harvester operational capacity (HOC) values were considered, which were calculated using the equation developed by Banchi (2017) (Eq. 6), using data on the agricultural productivity and operating life of the harvester in the respective year.

$$
\mathrm{HOC}=63.5-x^{0.308}-\frac{1188}{\mathrm{y}}
$$

where:

HOC - Harvester operational capacity, $\mathrm{Mg} \mathrm{h}^{-1}$;

$\mathrm{x}$ - operating life of the machine, $\mathrm{h}$; and,

y - agricultural productivity of sugarcane, $\mathrm{Mg} \mathrm{ha}^{-1}$.

With this information, Eq. 7 was applied to calculate the annual production of the harvester.

$$
\mathrm{PROD}=\text { HOC USE }
$$

where:

PROD - Harvester production, Mg year ${ }^{-1}$;

HOC - Harvester operational capacity, $\mathrm{Mg} \mathrm{h}^{-1}$; and,

USE - use of the harvester, $h$.

The range of factors that influence costs, such as exploration conditions, quality of the machines, or price relations, makes the coefficients used in the calculations particular, but distinct between the studied regions and countries (Lorencowicz \& Uziak, 2015).

Monetary values were updated according to the current reference data using the 2017 Extended Consumer Price Index (ECPI) from the Instituto Brasileiro de Geografia e Estatística (IBGE).

The equation parameters were defined using multiple nonlinear regression with the aid of MATLAB ${ }^{\circ}$ software. Following Montgomery \& Runger (2009), we performed statistical analysis using $\mathrm{R}$ software.

\section{Results ANd Discussion}

For estimating the variable costs (fuel, lubricating oil, and maintenance), their values were determined by the operating 
life of the equipment, and, for better analysis of this parameter, it was important to verify it every year, since, over time, the annual use (h) decreases due to the decrease in the mechanical availability of the equipment. In Figure 1, the evolution of the annual use in relation to operating life can be observed, according to the history of the studied plantations.

It can be observed that the annual use of the equipment has decreased according to its age, that is, when the equipment is new it has a potential use of $3,200 \mathrm{~h}_{\text {year }}{ }^{-1}$, and, this potential decreases to $2,120 \mathrm{~h}_{\text {year }}{ }^{-1}$ after six years of use. This is an indicator of the operating performance used to measure harvesting equipment (Cervi et al., 2015).

Regarding fuel costs, according to the computerized control system of the fleet, the average consumption of the harvesters accounted for $39.8 \mathrm{~L} \mathrm{~h}^{-1}$. This value is within the average values revealed in a study that identified an average consumption of $38.6 \mathrm{~L} \mathrm{~h}^{-1}$ at a $2100 \mathrm{rpm}$ (Ramos et al., 2016; Testa et al., 2016). Another datum on the fleet system is the average consumption of lubricating oils of harvesters, which accounted for $1.12 \mathrm{~L} \mathrm{~h}^{-1}$.

Since it was aimed to reveal the OC for several periods of operating life and agricultural productivity, a matrix was developed, ranging the harvester's operating life for six crops and agricultural productivity (Table 2).

The mathematical model representing the OC is shown in Eq. 8.

$$
\mathrm{OC}=4.54+0.000664 \mathrm{X}^{*}+\frac{210,700}{\mathrm{Y}^{2,6(* *)}}
$$

where:

$\mathrm{OC}$ - operating cost of harvester, $\mathrm{R} \$ \mathrm{Mg}^{-1}$;

$\mathrm{X}$ - operating life of the machine, $\mathrm{h}$;

$\mathrm{Y}$ - agricultural productivity of the cultivation, $\mathrm{Mg} \mathrm{ha}^{-1}$;

* - significance 0.05 ; and,

** - significance 0.01 .

Through statistical analysis of Eq. 10, a $\mathrm{R}^{2}$ of $96.3 \%$ was obtained.

Santos et al. (2014) conducted a study to identify the influence of harvest efficiency on the cost of production of sugarcane harvesters. They concluded that for both single- and double-row harvesters, a low harvest efficiency makes the cost unacceptable.

By ranging the values of $\mathrm{X}$ from 0 to $15,000 \mathrm{~h}$, and those of $\mathrm{Y}$ from 50 to $130 \mathrm{Mg} \mathrm{ha}^{-1}$, the values of the operating cost (OC) were simulated (Figure 2).

According to Figure 2, the harvester's operating life and the agricultural productivity influenced the OC per ton, since the cost ranges 7.23 to $26.43 \mathrm{R} \$ \mathrm{Mg}^{-1}$. Moreover, it is noted that the cost of the harvester $\left(\mathrm{R} \$ \mathrm{Mg}^{-1}\right)$ is inversely proportional to HOC. For a $35 \mathrm{Mg} \mathrm{h}^{-1} \mathrm{HOC}$, a cost of $\mathrm{R} \$ 6.00 \mathrm{Mg}^{-1}$ was obtained. On the other hand, for an HOC of $17 \mathrm{Mg} \mathrm{h}^{-1}$, the cost correspond to $\mathrm{R} \$ 16.50 \mathrm{Mg}^{-1}$. The aging of a harvester and the advancement of crops imply an increase in the cost of production within the same range of agricultural productivity.

Factors that influence the choice of systematization of mechanized harvesting can be one of the applications of this

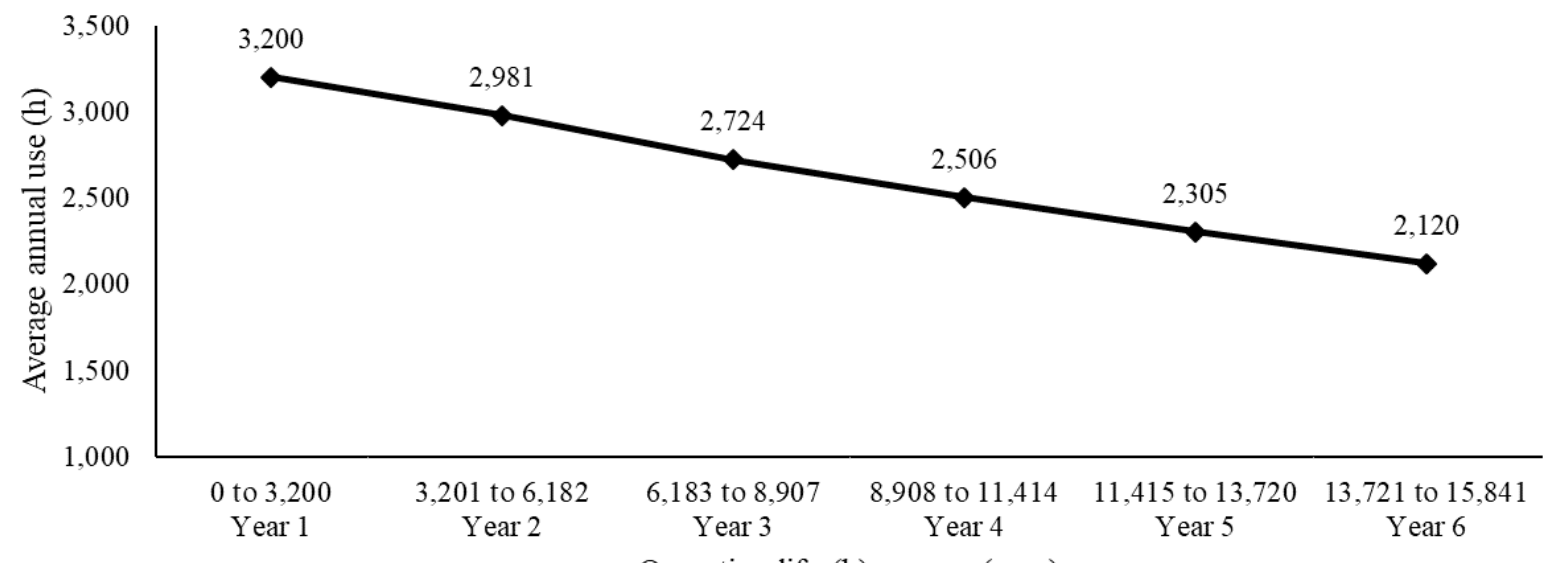

Figure 1. Annual use per range of operating life (h)

Table 2. Matrix of harvester operating cost (OC) according to different combinations of productivity and operating life

\begin{tabular}{|c|c|c|c|c|c|c|c|c|c|c|c|}
\hline \multirow{2}{*}{\multicolumn{2}{|c|}{ Operating life (h) }} & \multicolumn{9}{|c|}{ Operating cost ( $\left.\mathbf{R} \$ \mathrm{Mg}^{-1}\right)$} & \multirow{3}{*}{ Average } \\
\hline & & \multicolumn{9}{|c|}{ Agricultural productivity (Mg ha') } & \\
\hline Range & Average & 50 & 60 & 70 & 80 & 90 & 100 & 110 & 120 & 130 & \\
\hline $0-3,200$ & 1,600 & 10.75 & 9.50 & 8.77 & 8.29 & 7.96 & 7.71 & 7.51 & 7.36 & 7.23 & 8.34 \\
\hline $3,201-6,182$ & $4,691.5$ & 13.82 & 12.01 & 10.99 & 10.32 & 9.86 & 9.52 & 9.26 & 9.05 & 8.88 & 10.41 \\
\hline $6,183-8,907$ & 7,545 & 16.57 & 14.24 & 12.94 & 12.11 & 11.53 & 11.11 & 10.79 & 10.53 & 10.33 & 12.24 \\
\hline $8,908-11,414$ & 10,161 & 19.17 & 16.32 & 14.76 & 13.76 & 13.08 & 12.58 & 12.20 & 11.90 & 11.66 & 13.94 \\
\hline $11,415-13,720$ & $12,567.5$ & 21.67 & 18.30 & 16.47 & 15.32 & 14.54 & 13.96 & 13.52 & 13.18 & 12.90 & 15.54 \\
\hline $13,721-15,841$ & 14,781 & 24.07 & 20.19 & 18.10 & 16.80 & 15.91 & 15.26 & 14.77 & 14.39 & 14.07 & 17.06 \\
\hline $15,842-17,900$ & 16,871 & 26.43 & 22.03 & 19.68 & 18.23 & 17.24 & 16.52 & 15.98 & 15.55 & 15.20 & 18.54 \\
\hline \multicolumn{2}{|c|}{ Average } & 18.93 & 16.08 & 14.53 & 13.55 & 12.87 & 12.38 & 12.00 & 11.71 & 11.47 & 14.93 \\
\hline \multirow{2}{*}{\multicolumn{2}{|c|}{$\begin{array}{l}\text { S.D. } \\
\text { C. }\end{array}$}} & 5.19 & 4.15 & 3.61 & 3.29 & 3.07 & 2.92 & 2.80 & 2.71 & 2.64 & 3.85 \\
\hline & & 27.40 & 25.80 & 24.90 & 24.30 & 23.90 & 23.60 & 23.30 & 23.20 & 23.00 & 25.80 \\
\hline
\end{tabular}

S.D. - Standard deviation, \%; C.V. - Coefficient of variation 
A.
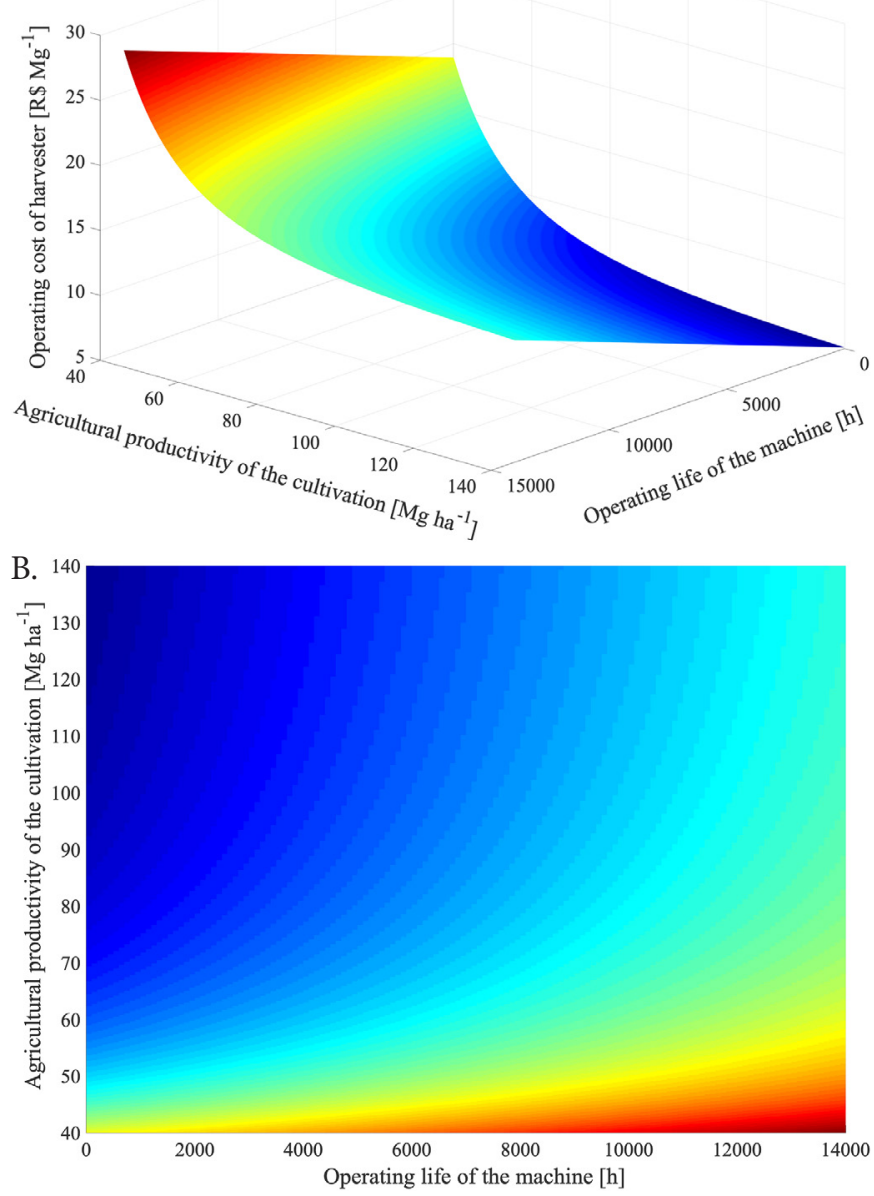

Figure 2. Response surface operating cost (OC) simulation (A) OC in function of the operating life of the machine and agricultural productivity of the cultivation; (B) on a flat surface

index (Solano et al., 2017). It can also assist in the calculation of outsourcing contracts for mechanized sugarcane cutting operations in processing plants, since supporting parameters for defining these contracts are scarce. The OC has great influence in the definition of the economic performance, both for the processing plants and companies that provide this service.

According to Santos et al. (2016a), the most influential variables regarding the total cost of operation are effective working hours, workforce, maintenance and repairs, fuel, and depreciation, which are factors measured in this method for estimating the OC.

\section{Conclusions}

1. A mathematical model was adjusted that determines the operating cost of a sugarcane harvester, based on agricultural productivity of the cultivation and operating life of the haverster.

2. This cost model allows to verify that the operating cost of a harvester $\left(\mathrm{R} \$ \mathrm{Mg}^{-1}\right)$ decreases as the agricultural productivity of the cultivation increases $\left(\mathrm{Mg} \mathrm{ha}^{-1}\right)$, and it increases as the age of the haverster also increases (operating life), and both variables exhibit nonlinear variation.

\section{Literature Cited}

Banchi, A. D. Impacto da produtividade agrícola e da vida dos equipamentos na produção e no custo da colhedora de canade-açúcar. Campinas: UNICAMP, 2017. 144p. Tese Doutorado

Banchi, A. D.; Lopes, J. R.; Zago, C. A. Estudo dos custos com reparo e manutenção em colhedoras de cana-de-açúcar: Parte I. Revista Agrimotor, v.38, p.12-13, 2008.

Cervi, R. G.; Esperancini, M. S. T.; Silva, H. de O. F.; Isler, P. R.; Oliveira, P. A. de. Avaliação do desempenho operacional da colheita e transbordo de cana-de-açúcar (Saccharum spp.). Revista Energia na Agricultura, v.30, p.232-241, 2015. https:// doi.org/10.17224/EnergAgric.2015v30n3p232-241

Ebadian, M.; Shedden, M. E.; Webb, E.; Sokhansanj, S.; Eisenbies, M.; Volk, T.; Heavey, J.; Hallen, K. Impact of parcel size, field shape, crop yield, storage location and collection equipament on the performance of single-pass cut-and chip harvest system in commercial shrub willow fields. BioEnergy Research, v.11, p.364381, 2018. https://doi.org/10.1007/s12155-018-9902-7

Galvão, C. B.; Garcia, A. P.; Albiero, D.; Ribeiro, A. Í.; Banchi A. D. Operational management of the cane infield wagon: Analysis of the cost of repair and maintenance. Revista Brasileira de Engenharia Agrícola e Ambiental, v.22, p.218-222, 2018. https:// doi.org/10.1590/1807-1929/agriambi.v22n3p218-222

IBGE - Instituto Brasileiro de Geografia e Estatística. 2018. Available on: <https://sidra.ibge.gov.br/pesquisa/lspa/tabelas >. Accessed on: Jan. 2018.

Lorencowicz, E.; Uziak, J. Repair cost of tractors and agricultural machines in family farms. Agriculture and Agricultural Science Procedia, v.7, p.152-157, 2015. https://doi.org/10.1016/j.aaspro.2015.12.010

Montgomery, D. C.; Runger, G. C. Estatística aplicada e probabilidade para engenheiros. 4.ed. Rio de Janeiro: LTC, 2009. 496p.

Pereira, A. L. N.; Lopes, E. da S.; Dias, A. N. Análise técnica e de custo do feller buncher e skidder na colheita de madeira em diferentes produtividades do povoamento. Ciência Florestal, v.25, p.981-989, 2015. https://doi.org/10.5902/1980509820659

Pereira, N. A. Variáveis de custos de produção da cana-de-açúcar e suas diferenças entre as regiões produtoras. Revista em Agronegócio e Meio Ambiente, v.10, p.757-774, 2017. https://doi. org/10.17765/2176-9168.2017v10n3p757-774

Ramos, C. R. G.; Lanças, K. P.; Lyra, G. A. de; Sandi, J. Fuel consumption of a sugarcane harvester in different operational settings. Revista Brasileira de Engenharia Agrícola e Ambiental, v.20, p.588-592, 2016. https://doi.org/10.1590/1807-1929/ agriambi.v20n6p588-592

Santos, D. W. F. do N.; Valente, D. S. M.; Fernandes, H. C.; Forastiere, P. R.; Silva, R. M. F. Análise técnica do harvester operando em dois subsistemas de colheita de madeira. Revista Engenharia na Agricultura, v.24, p.484-490, 2016a. https://doi.org/10.13083/ reveng.v24i6.725

Santos, L. N. dos; Fernandes, H. C.; Silva, M. L. da; Teixeira, M. M.; Souza, A. P. de. Avaliação de custos da operação de extração da madeira com forwarder. Cerne, v.22, p.27-34, 2016b. https://doi. org/10.1590/01047760201622012076

Santos, N. B.; Cavalcante, D. S.; Fernandes, H. C.; Gadanha Júnior, C. D. Simulação da eficiência de campo da colheita mecanizada de cana-de-açúcar (Saccharum spp.). Revista Energia na Agricultura, v.29, p.9-13, 2014. https://doi.org/10.17224/ EnergAgric.2014v29n1p09-13 
Solano, C. S.; Ponciano, N. J.; Azevedo, H. J. de; Souza, P. M. de. Factors limiting the implementation of mechanical harvesting of sugarcane in Campos dos Goytacazes, RJ, Brazil. Revista Ceres, v.64, p.40-46, 2017. https://doi.org/10.1590/0034$737 \times 201764010006$
Testa, J. V. P.; Lanças, K. P.; Martins, M. B.; Sandi, J.; Drudi, F. S. Desempenho operacional e energético de colhedoras de canade-açúcar (Saccharum spp.) para uma e duas linhas de cultura. Revista Energia na Agricultura, v.31, p.253-258, 2016. https://doi. org/10.17224/EnergAgric.2016v31n3p253-258 